\title{
Seasonal Changes in Serum Total Thyroxine, Free Thyroxine, and Canine Thyroid- Stimulating Hormone in Clinically Healthy Beagles in Hokkaido
}

\author{
Eiji OOHASHI ${ }^{1,2)}$, Katsuyoshi YAGI ${ }^{1}$, Yuji UZUKA ${ }^{1)}$, Shigeyuki TANABE ${ }^{1)}$, Takao SARASHINA ${ }^{1)}$ and \\ Takuo ISHIDA ${ }^{3)}$ \\ ${ }^{1)}$ Laboratory of Veterinary Internal Medicine, Department of Veterinary Medicine, Obihiro University of Agriculture and Veterinary \\ Medicine, Inada-cho, Obihiro, Hokkaido 080-8555, ${ }^{2}$ Akashiya Animal Clinic, Satsunai Sakura-machi, Makubetsu-cho, Nakagawa-gun, \\ Hokkaido 089-0535 and ${ }^{3)}$ Akasaka Animal Clinic, 4-1-29 Akasaka, Minato-ku, Tokyo 107-0052, Japan
}

(Received 19 February 2001/Accepted 27 July 2001)

ABSTRACT. The purpose of this study was to evaluate seasonal influences on thyroid hormone levels of healthy outdoor dogs in Hokkaido. We surveyed serum basal total thyroxine $\left(\mathrm{tT}_{4}\right)$, free thyroxine $\left(\mathrm{fT}_{4}\right)$, and canine thyroid-stimulating hormone (cTSH) levels, and $\mathrm{tT}_{4}$ levels after administration of TSH for a year. Basal $\mathrm{tT}_{4}$ levels decreased in January, and increased in August and September. $\mathrm{fT}_{4}$ levels increased in January and November. No significant seasonal variation was found in $\mathrm{cTSH}$. $\mathrm{tT}_{4}$ levels after administration of TSH in August and November increased. These results suggested that the thyroid gland may have been activated in November. We should take seasonal variation into consideration when thyroid function is tested.

KEY WORDS: canine, season, thyroid hormone.

J. Vet. Med. Sci. 63(11): 1241-1243, 2001

Recent progress in the development of hormone assays has made thyroid function testing for dogs more precise [1, 8]. Advances in the ability to measure serum free thyroxine $\left(\mathrm{fT}_{4}\right)$ by dialysis $[6,9]$ and serum canine thyroid-stimulating hormone (cTSH) [9] levels have contributed to this. By using these tests in combination with the thyrotropin-releasing hormone (TRH)-stimulating test [14] and the TSH-stimulating test [5], researchers can now examine in detail the influence of the hypothalamus-pituitary-thyroid axis on thyroid function. The above tests make it possible to examine previously undetectable minute physiological changes in thyroid function. Many studies have reported that thyroid function in humans adapts to environmental conditions such as ambient temperature, photoperiod, and season, but the results have not been consistent because more than one parameter may mediate thyroid function $[2-4,10]$. Although similar findings were reported in rat $[11,13]$, sheep [15], and dog [12], the only hormones measured were serum total thyroxine $\left(\mathrm{tT}_{4}\right)$, triiodothyronine $\left(\mathrm{tT}_{3}\right)$, and $\mathrm{TSH}$. There has been only one report about seasonal changes in thyroid function in the dog [12], but the details of such changes have remained unclear because only $\mathrm{tT}_{4}$ and $\mathrm{tT}_{3}$ levels were measured.

The purpose of the present study was to evaluate the influence of the season on the thyroid hormone levels of healthy outdoor dogs. We surveyed basal $\mathrm{tT}_{4}, \mathrm{fT}_{4}, \mathrm{cTSH}$ levels, and $\mathrm{tT}_{4}$ levels after administration of $\mathrm{TSH}$ for a year. Subject dogs - Ten clinically healthy beagles were used, ranging in age from 2 to 7 years and weighing 8.0 to $15.0 \mathrm{~kg}$. There were 7 males and 3 females. The dogs were separated into two groups by sex, and had been raised outdoors since

\footnotetext{
* Correspondence to: Oohashi, E., Akashiya Animal Clinic, Satsunai Sakura-machi, Makubetsu-cho, Nakagawa-gun, Hokkaido 089-0535, Japan.
}

puppyhood, fed a standard commercial dry dog food once daily at 4 p.m., and given water freely at the Laboratory of Veterinary Internal Medicine, Obihiro University of Agriculture and Veterinary Medicine. Exposure to sunlight was good even though the outdoor runs had roofs. Wind did not blow strongly because of surrounding buildings. The history and results of routine physical examinations and routine laboratory tests (CBC, total cholesterol, ALT, ALP, BUN, and creatinine) were unremarkable for all dogs at each blood sampling during the entire survey period.

Measurement items: cTSH levels were measured in all dogs. In 6 of the 10 dogs, $\mathrm{fT}_{4}$ and basal $\mathrm{tT}_{4}$ levels were measured and a TSH-stimulating test was performed. In each of the $6 \mathrm{dogs}, 0.1 \mathrm{U} / \mathrm{kg}$ bovine-TSH (Sigma Chemical Co., U.S.A.) was administered IV, and a measurement sample of serum $\mathrm{tT}_{4}$ was obtained $6 \mathrm{hr}$ after TSH administration [8].

Sampling: The survey period was from December 1997 to November 1998. Blood samples were collected at 8 a.m. once a month throughout the survey period. The dogs were fasted for at least $12 \mathrm{hr}$ before blood collection through a venipuncture of the cervical vein. The serum was separated and stored at $-80^{\circ} \mathrm{C}$ until hormonal determination.

Hormone assays: Radioimmunoassay with a commercial kit (Coat-A-Count, Canine $\mathrm{T}_{4}{ }^{\circledR}$, Diagnostic Products Co., U.S.A.) and immunoradiometric assay (Coat-A-Count, Canine TSH ${ }^{\circledR}$, Diagnostic Products Co., U.S.A.) were used for the determination of $\mathrm{tT}_{4}$ and cTSH levels, respectively. Each determination was done in duplicate. A commercial laboratory (IDEXX Laboratories Co., Japan) measured $\mathrm{fT}_{4}$ levels by equilibrium dialysis.

Analysis of data: The data were analyzed by Two-way ANOVA or the Friedman test after the Bartlett test. Multiple comparison test was applied with Fisher's PLSD to assess statistical significance. A value of $\mathrm{P}<0.05$ was considered statistically significant. 
The monthly average ambient temperatures in our institution during the study were as follows: December $-5.0^{\circ} \mathrm{C}$, January $-11.7^{\circ} \mathrm{C}$, February $-8.7^{\circ} \mathrm{C}$, March $-0.7^{\circ} \mathrm{C}$, April $+7.2^{\circ} \mathrm{C}$, May $+11.1^{\circ} \mathrm{C}$, June $+12.7^{\circ} \mathrm{C}$, July $+17.0^{\circ} \mathrm{C}$, August $+17.9^{\circ} \mathrm{C}$, September $+16.4^{\circ} \mathrm{C}$, October $+10.1^{\circ} \mathrm{C}$, and November $+1.1^{\circ} \mathrm{C}$. The average $\mathrm{tT}_{4}, \mathrm{fT}_{4}$, and cTSH values are listed in Table 1. As shown in Table 1, the basal $\mathrm{tT}_{4}$ level in January was the lowest, and was significantly lower than in the nine other months. Basal $\mathrm{tT}_{4}$ levels in March, August, and September were significantly higher than in the seven to nine other months. Basal $\mathrm{fT}_{4}$ levels in January and November were significantly higher than in the eight to ten other months. No significant variation was found in serum cTSH levels among the twelve months. Table 2 summarizes $\mathrm{tT}_{4}$ levels after administration of $\mathrm{TSH}$. The $\mathrm{tT}_{4}$ average values after administration of TSH in both August and November were significantly higher than in June and July, and the level in November was also significantly higher than in December.

There is only one published report about seasonal change in thyroid function in dogs, that of Tuckova et al. of Slovakia [12]. Their data showed increased $\mathrm{tT}_{4}$ levels in autumn and decreased $\mathrm{tT}_{4}$ levels in summer, but in our present study, the $\mathrm{tT}_{4}$ level decreased in January (midwinter) and increased in March (early spring), August (late summer), and September (early autumn). Reports about seasonal differences in human thyroid function are available. Nishi et al. [4] reported that TSH and $\mathrm{fT}_{3}$ levels were higher during winter than in summer, but no such change was observed with $\mathrm{fT}_{4}$ levels in healthy subjects in Sapporo Japan. Leppaluto et al. of Finland [3] reported that $\mathrm{fT}_{3}$ levels were lower in February than in August and TSH levels were higher in December than in other months, and that $\mathrm{fT}_{4}, \mathrm{tT}_{4}$, and $\mathrm{tT}_{3}$ levels were unchanged. So that the results vary geographically, and the influences of ambient temperature and photoperiod are thought to account for these regional differences. It could be thought that the different results for dogs in Hokkaido and Slovakia were also caused by differences in ambient temperature or photoperiod. In our present study, in January, the basal $\mathrm{tT}_{4}$ decreased and the $\mathrm{fT}_{4}$ increased, although the cTSH and $\mathrm{tT}_{4}$ after administration of TSH did not change. A decreased $\mathrm{tT}_{4}$ level is not specific for a diagnosis of canine hypothyroidism. $\mathrm{tT}_{4}$ consists of $\mathrm{T}_{4}$ bound to plasma proteins $\left(\mathrm{bT}_{4}\right)$ and $\mathrm{fT}_{4}$. Although the $\mathrm{bT}_{4}$ level in euthyroid dogs is often decreased by many factors, such as changes in hormone binding to serum carrier proteins, and changes in peripheral hormone distribution and metabolism, $\mathrm{fT}_{4}$ is less affected by them. Because only free hormone can enter cells and bind to receptors, measurement of $\mathrm{fT}_{4}$ should give a more accurate representation of thyroid function [8]. In our study, it was thought that thyroid function was not decreased in January, because the $\mathrm{fT}_{4}$ level was increased and the $\mathrm{tT}_{4}$ level post $\mathrm{TSH}$ was not decreased. Solter et al. [10] reported that, in healthy workers exposed to cold environment, the $\mathrm{tT}_{4}$ level decreased, the $\mathrm{fT}_{4}$ level increased or did not change, and thyroxine-binding globulin (TBG) decreased. Therefore, the higher $\mathrm{fT}_{4}$ level noted in our present data in January may have been caused by the decreased $\mathrm{bT}_{4}$, although TBG was not measured at that time. The $\mathrm{tT}_{4}$ level decreases when the cortisol level is high [8].

Table 1. Seasonal variation in serum Basal $\mathrm{tT}_{4}, \mathrm{fT}_{4}$ and $\mathrm{cTSH}$ levels in healthy beagles in Hokkaido (mean $\pm \mathrm{SD}$ )

\begin{tabular}{|c|c|c|c|c|c|c|c|c|c|c|c|c|}
\hline & \multicolumn{3}{|c|}{ Winter } & \multicolumn{3}{|c|}{ Spring } & \multicolumn{3}{|c|}{ Summer } & \multicolumn{3}{|c|}{ Autumn } \\
\hline & Dec & Jan & Feb & Mar & Apr & May & Jun & Jul & Aug & Sep & Oct & Nov \\
\hline \multirow[t]{2}{*}{ Basal $\mathrm{tT}_{4}(\mathrm{nmol} / l)$} & 14.4 & $11.3^{\mathrm{a})}$ & 15.1 & $20.7^{\mathrm{b})}$ & 14.6 & 14.0 & 15.4 & 14.3 & $18.7^{\mathrm{e})}$ & $18.7^{\mathrm{d})}$ & 17.0 & 17.1 \\
\hline & \pm 3.1 & \pm 1.7 & \pm 1.4 & \pm 2.5 & \pm 3.4 & \pm 1.2 & \pm 2.6 & \pm 3.4 & \pm 2.6 & \pm 3.3 & \pm 4.0 & \pm 1.2 \\
\hline \multirow{2}{*}{ Basal $\mathrm{fT}_{4}(\mathrm{pmol} / l)$} & 18.0 & $44.5^{\mathrm{e})}$ & 24.6 & 30.1 & 17.3 & 16.5 & 17.6 & 17.2 & 18.6 & 26.3 & 19.2 & $39.0^{f)}$ \\
\hline & \pm 8.4 & \pm 20.8 & \pm 6.6 & \pm 5.2 & \pm 3.2 & \pm 3.1 & \pm 1.6 & \pm 4.8 & \pm 4.0 & \pm 7.8 & \pm 5.2 & \pm 31.5 \\
\hline \multirow[t]{2}{*}{ Basal cTSH $(n \mathrm{~g} / \mathrm{m} l)$} & 0.18 & 0.26 & 0.26 & 0.36 & 0.36 & 0.38 & 0.41 & 0.30 & 0.38 & 0.33 & 0.34 & 0.17 \\
\hline & \pm 0.22 & \pm 0.14 & \pm 0.14 & \pm 0.25 & \pm 0.20 & \pm 0.54 & \pm 0.81 & \pm 0.62 & \pm 0.71 & \pm 0.23 & \pm 0.48 & \pm 0.12 \\
\hline
\end{tabular}

a) Basal $\mathrm{tT}_{4}$ level in January is significantly lower than in Dec, Feb, Mar, Apr, Jun, Aug, Sep, Oct, and Nov.

b)-d) Basal $\mathrm{tT}_{4}$ levels in March, August, and September are significantly higher than in Dec, Jan, Feb, Apr, May, Jun, and Jul. Basal $\mathrm{tT}_{4}$ level in March is also significantly higher than in Oct and Nov.

e), f) Basal $\mathrm{fT}_{4}$ levels in both January and November are significantly higher than in Dec, Feb, Apr, May, Jun, Jul, Aug, and Oct. Basal $\mathrm{fT}_{4}$ level in January is also significantly higher than in Mar and Sep.

Table 2. Seasonal variation in serum $\mathrm{tT}_{4}$ levels $6 \mathrm{hr}$ after administration of $0.1 \mathrm{U} / \mathrm{kg} \mathrm{TSH}$ in healthy beagles in Hokkaido (mean $\pm \mathrm{SD})$

\begin{tabular}{|c|c|c|c|c|c|c|c|c|c|c|c|c|}
\hline & \multicolumn{3}{|c|}{ Winter } & \multicolumn{3}{|c|}{ Spring } & \multicolumn{3}{|c|}{ Summer } & \multicolumn{3}{|c|}{ Autumn } \\
\hline & Dec & Jan & Feb & Mar & Apr & May & Jun & Jul & Aug & Sep & Oct & Nov \\
\hline $\mathrm{tT}_{4}$ post $\mathrm{TSH}(\mathrm{nmol} / l)$ & $\begin{array}{r}20.8 \\
\pm 7.1\end{array}$ & $\begin{array}{r}22.0 \\
\pm 2.8\end{array}$ & $\begin{array}{r}22.8 \\
\pm 9.2\end{array}$ & $\begin{array}{r}28.0 \\
\pm 8.8\end{array}$ & $\begin{array}{c}23.9 \\
\pm 11.2\end{array}$ & $\begin{array}{c}22.1 \\
\pm 8.8\end{array}$ & $\begin{array}{r}20.1 \\
\pm 8.2\end{array}$ & $\begin{array}{c}20.2 \\
\pm 7.9\end{array}$ & $\begin{array}{c}30.4^{\mathrm{a})} \\
\pm 12.1\end{array}$ & $\begin{array}{r}28.4 \\
\pm 7.9\end{array}$ & $\begin{array}{r}26.6 \\
\pm 9.8\end{array}$ & $\begin{array}{l}31.9^{\mathrm{b})} \\
\pm 7.8\end{array}$ \\
\hline
\end{tabular}

a) b) $\mathrm{tT}_{4}$ post TSH levels in both August and November are significantly higher than in Jun and Jul. $\mathrm{tT}_{4}$ post TSH level in November is also significantly higher than in Dec. 
Exposure to cold in January might create a condition like Cushing's syndrome because of stress, although the cortisol level was not measured in the present study. Many reports about the influence of environmental temperature--specifically, exposure to cold--on the thyroid hormones of the human being $[2,7]$ and rat $[11,13]$ suggest that cold exposure activates pituitary and thyroid functions and increases the basal metabolic rate. In our present study, the response to the TSH-stimulating test was increased in August and November. The thyroid gland may have reacted against the progressive decrease in ambient temperature in order to increase the basal metabolic rate in November (late autumn) because the $\mathrm{fT}_{4}$ level increased. It was not possible to know the exact reasons for increased $\mathrm{tT}_{4}$ response to $\mathrm{TSH}$ in August, and those for increased $\mathrm{tT}_{4}$ levels in March, August and September in this survey.

These results suggest that thyroid hormone levels vary according to the season in healthy outdoor dogs. We should take seasonal variation into consideration when thyroid function is tested. It might be necessary to investigate other factors, such as the photoperiod or regional differences, and to do other thyroid function tests such as measurements of triiodothyronine or TRH stimulation test, to evaluate the cause of the seasonal change in detail.

ACKNOWLEDGMENT. We would like to thank IDEXX Laboratories Co. Japan for measurement of $\mathrm{fT}_{4}$. This work was supported in part by Grant-in-Aid from Kuribayashi Foundation.

\section{REFERENCES}

1. Ferguson, D. C. and Hoening, M. E. 1991. pp. 845-864. In: Small Animal Medicine (Allen, D. G. ed.), J.B. Lippincott, Philadelphia.

2. Harford, R. R. and Reed, H. L. 1993. Metabolism 42: 11591163.

3. Leppaluto, J., Sikkila, K. and Hassi, J. 1998. Int. J. Circumpolar Health 57: 383-385.

4. Nishi, I., Ichihara, K., Takeoka, K., Miyai, K. and Amino, N. 1996. Rinsyo Byori 44: 159-162.

5. Oliver, J. W. and Waldrop, V. 1983. J. Am. Vet. Med. Assoc. 182: 486-489.

6. Peterson, M. E., Melian, C. and Nichols, R. 1997. J. Am. Vet. Med. Assoc. 211: 1396-1402.

7. Reed, H.L. 1995. Arctic Med. Res. 54: 9-15.

8. Scott-Moncrieff, J. C. and Guptill-Yoran, L. 2000. pp. 14191429. In: Textbook of Veterinary Internal Medicine, 5th ed. (Ettinger, S. J. and Feldman, E. D. eds.), B. W. Saunders, Philadelphia.

9. Scott-Moncrieff, J. C., Nelson, R. W., Bruner, J. M. and Williams, D. A. 1998. J. Am. Vet. Med. Assoc. 212: 387-391.

10. Solter, M., Brkic, K., Petek, M., Posavec, L. and Sekso, M. 1989. J. Clin. Endocrinol. Metab. 68: 168-172.

11. Tang, F., Wong, T. M. and Loh, T. T. 1988. Horm. Metab. Res. 20: 616-619.

12. Tuckova, M., Fialkovicova, M., Baranova, D., Bekeova, E. Kozak, M. and Palenik, L. 1995. Vet. Med. (Praha) 40: 249 252.

13. Whitaker, E. M., Hussain, S. H., Hervey, G. R., Tobin, G. and Rayfield, K.M. 1990. J. Physiol. 431: 543-556.

14. Yagi, K., Ohashi, E., Uzuka, Y., Tanabe, S. and Sarashina, T. 2000. Vet. Rec. 146: 706-707.

15. Webster, J.R., Moenter, S.M., Woodfill, C.J. and Karsch, F.J. 1991. Endocrinology 129: 176-183. 